\title{
Perceived Social Support, Depression and Life Satisfaction as the Predictor of the Resilience of Secondary School Students: The Case of Burdur
}

\author{
Hülya ŞAHİN BALTACI* \\ Zeynep KARATAŞ ${ }^{* *}$
}

\section{Suggested Citation:}

Sahin-Baltaci, H., \& Karatas, Z. (2015). Perceived social support, depression and life satisfaction as the predictor of the resilience of secondary school students: The case of Burdur. Eurasian Journal of Educational Research, 60, 111-130 10.14689/ejer.2015.60.7

\begin{abstract}
Problem statement: It has been observed that there are a limited number of studies on the resilience of primary and secondary school students in Turkey. However, it is acknowledged that secondary school students with difficult conditions of life also have to cope with rapid physical, psychological and social changes brought about by adolescence. For this reason, conducting research on the resilience characteristics of students within this age range would be an opportunity to enable them to acquire the abilities that will increase their resilience level. Moreover, the findings obtained from this research would contribute to the acknowledgement of protective factors, especially crisis response studies in the fields of psychological counseling and guidance services.

Purpose of the Study: The general purpose of this research is to analyze perceived social support, depression and life satisfaction as predictors of the resilience of secondary school students of low socioeconomic levels. The examination of students' levels of resilience was based on gender, who they lived with, and whether their parents were together/separated and were alive/not alive.

Method: The study group of the research consists of 386secondary school students. Of the students in the sample, 202 (52\%) are girls, and $184(48 \%)$ are boys. Of these students, $130(34 \%)$ attend sixth-grade, $138(36 \%)$ attend
\end{abstract}

* Corresponding author: Dr. Pamukkale Üniversitesi, Department of Educational Sciences. PDR.ABD e-mail: hbaltaci@pau.edu.tr,

** Dr. Mehmet Akif Ersoy Üniversitesi. , Department of Educational Sciences, PDR.ABD. eMail:zeynepkaratas@mehmetakif.edu.tr 
seventh-grade, and 118 (30\%) attend eighth-grade. In this research used the relational screening method. To obtain the data for the Resilience Scale for Secondary School Students, The Brief Multidimensional Students' Life Satisfaction Scale (BMSLSS), Social Support Appraisal Scale for Children and Adolescents and Depression Scale for Children were used. A t-test, one-way analysis of variance, and multi-standard linear regression analysis were used for data analysis in the research.

Findings and Results: The results obtained from the research indicate that perceived social support and life satisfaction significantly predict resilience, whereas depression is not a significant predictor of resilience. Moreover, the resilience of students does not express a significant difference based on gender. The resilience levels of students who live with their parents and whose parents are together was found to be higher when compared to other students.

Conclusions and Recommendation: First of all, in order to increase their resilience abilities, psychological training can be provided through counseling in schools for students who live with only one of their parents or their relatives. Within the scope of student personality services, various social support resources can be allocated for secondary school students whose parents have separated and the father/mother is/are not alive. Since social support and life satisfaction are important variables in regard to resilience, an appropriate education-teaching environment can be provided for such studies to be conducted at schools. In considering schools as important social support elements, increasing school services that meet the needs of the students and transforming the school into an important living area that encourages students to love school can be useful. This can be achieved through sports activities, functional clubs, and creating environments where students can comfortably express themselves. İn order to increase resilience levels, psycho-training program start getting risk groups can be developed, and these programs can be experimentally tested. The most important restriction of this study is that the sample group consisted of students living in Burdur, a small city that does not receive many immigrants.

Keywords: Well-being, gender, stressful life events, adolescents

\section{Introduction}

Resilience is defined as the ability to cope with and adjust to stress or difficult situations (Garmezy, 1991; Masten, 2001; Masten, Best \& Garmezy, 1990, cited in Hand, 2008; Luthar, Cicchetti \& Becker, 2000). In this process, which is defined as a successful adaptation to adverse situations, the personality traits of individuals are an important factor. Personality traits are one of the elements that lead to healthy consequences after stressful situations (Reich, Zautra \& Hall, 2010). Two basic factors are emphasized in the concept of resilience. The first focuses on relief from stressful 
life events, in spite of those events, and the ability to recover from stress and rapidly reestablish balance. The second factor is sustainability, which can be expressed as the ability to sustain healthy reactions to other situations of stress as a result of reacting healthily to stressful life events (Reich, Zautra \& Hall, 2010).

Benard (1991) emphasized that the provision of the appropriate environmental conditions are required in order to bring up resilient individuals and stated that resilient children have social competence, problem-solving ability, autonomy, and feelings of purpose, and hope for the future. Adult support is one of the important protective factors for the child to be able to see and to solve problems. Social support is noted to bean important variable in sustaining healthy behavior (Celikel \& Erkorkmaz, 2008). At the same time, social support is defined as the information that enables the individual to believe that he/she is loved, valued, cared for and a member of a social network (Cobb, 1976). Individuals with strong social support systems have been found to be good at coping with stressful life events (Callaghan \& Morrissey, 1993; Shonkoff, 1984) and overcoming psychological problems (Lara, Leader \& Klein, 1998), and they experience less anxiety, behavioral problems and depressive symptoms (Barrera, Fleming \& Khan, 2004). Less social support affects the level of resilience as a protective factor in individuals and also is important in terms of the observance frequency of depressive symptoms. Depression is generally revealed as negative thoughts, disappointment, hopelessness and reluctance (Cicchetti \& Toth, 1998). A negative perspective towards the world during the early childhood years teaches individuals to disappoint themselves. The negative aspects of experienced situations become more serious, and life situations that are sources of heavy stress increase the risk of depression (Erdogan, 2006). Motivational symptoms observed in depression include apathy and boredom, whereas physical symptoms can consist of sleeping problems, loss of energy and appetite (Steinberg, 2002).

In contrast to individuals with depression, those who love life try various ways to hold onto life and make an effort to overcome difficult situations and pull themselves together. Obtaining satisfaction from life supports this effort. Life satisfaction is closely related to morale, adaptation and psychological well-being (McDowell, 2010). Life satisfaction includes the cognitive judgments of people on their own life and is considered the basic component of the person's subjective well-being (Joshanloo, 2013). Life satisfaction refers to a person's internal subjective assessment of his/her life quality. As the level of life satisfaction lowers in children and adolescents, extroversion, internal locus of control, self-concept, active coping, and pro-social behavior decrease, while addictive substance use and psychopathological behavior increase (Huebner, 2004). Self-esteem enhancing skills and stress-coping skills were significant predictors of secondary school students' life satisfaction (Sahin-Baltaci, 2013). In addition, positive family characteristics affect the resilience of children positively. Positive relationships with neighbors outside of the family and the positivity of relationships with friends and teachers are also among the factors that increase resilience (Soest, Mossige, Stefansen \& Hjemdal, 2009).

Numerous descriptive studies were examined (Werner \& Smith, 1982; Masten, 1994; Luthar, Cicchetti \& Becker, 2000; Masten, 2001; Greene, 2002; Fergus \& Zimmerman, 2005; Ahern, Ark \& Byers, 2008; Clinton, 2008; Davis, Luecken \& 
Lemery-Chalfant, 2009; Smith, 2009; Salami, 2010; Wilks \& Spivey, 2010; Hanewald, 2011; Rose \& Steen, 2015; Coleman, 2015). It has been observed that the studies in Turkey are mostly descriptive (Ogulmus, 2001; Gizir, 2004; Ozcan, 2005; Eminagaoglu, 2006; Karairmak, 2006; Gokden Kaya, 2007; Karairmak, 2007; Dayioglu, 2008; Oktan, 2008; Onder \& Gulay, 2008; Sipahioglu, 2008; Terzi, 2008; Oz \& Bahadir-Yilmaz, 2009; Bayrakli, 2010; Guloglu \& Karairmak, 2010; Kirimoglu, Yildirim \& Temiz, 2010; Onat, 2010; Kaner, Bayrakli\& Guzeller, 2011; Karatas\& Savi Cakar, 2011; Karairmak \& Sivis-Cetinkaya, 2011; Savi-Cakar \& Karatas, 2011, Yilmaz \& Sipahioglu, 2012;Savi-Cakar, Karatas, Cakir, 2014; Malkoc\& Yalcin, 2015).

Gizir (2004) analyzed the academic resilience of eighth-grade students in primary education and determined that high expectations at home, attention and affection in relationships at school, and attention and affection in friendships are the most basic external protective factors that predict the academic resilience of economically poor students. Ozcan (2005) stated that the level of resilience and protective factors in high school students whose parents are together is higher than those whose parents are divorced; also, there is not a significant difference in their resilience based on gender. Eminagaoglu (2006) found that street children between the ages of 12-16 are rather inclined to cooperative behavior and establishing emotional affection. Their emotional ties within groups of friends are the most important characteristic of resilience in their lives. Gokden Kaya (2007) studied the roles of self-respect, hope, and external factors in the prediction of resilience of second-grade students attending regional primary boarding schools and found that these factors predict resilience at a significant level. Dayioglu (2008) found that learned strength, perceived social support and gender significantly predict the resilience of adolescents who are preparing for the university examination. Moreover, Dayioglu stated that the resilience of males is higher than females.

Oktan (2008) obtained the result that the resilience of adolescents preparing for the university examination indicated a significant difference based on problemsolving ability and life satisfaction. Onder and Gulay (2008) detected a significant relationship between the self-concept and the resilience of eighth-grade students. Furthermore, they found that the resilience of girls was higher than that of boys. Sipahioglu (2008) found that the resilience of adolescents in different risk groups differed based on the variables of poverty (with his/her family), living with a single parent, gender and type of school. Onat (2010) stated that the levels of resilience of first-grade high school students who perceive their parents democratically are significantly higher. In addition, students' levels of resilience were found to differ significantly based on the school that the child currently attends, the child's age, number of siblings, family's monthly income, mother's level of education, parents' professions, where the child's father grew up, level of protective attitude adopted by the parents, and the attitude adopted by the parents while bringing up the child. Karatas and Savi-Cakar (2011) found that self-esteem and hopelessness are significant predictors of resilience in adolescents. Savi-Cakar and Karatas (2011) found that the social support perceived by adolescents predicts their level of resilience significantly. There is a positive relationship between the resilience level of adolescents and the social support they receive from their family, friends and 
teachers, and resilience levels differ based on gender so that girls have a higher level of resilience compared to boys.

İt has been observed that there are a limited number of studies on the resilience of primary and secondary school students in Turkey (Gokden Kaya, 2007; Onder \& Gulay, 2008). However, it is acknowledged that secondary school students living under difficult conditions also have to cope with rapid physical, psychological and social changes brought about by adolescence. For this reason, conducting research on the resilience characteristics of students within this age range would lead to a better understanding of how they can acquire the abilities that will increase their resilience levels. Moreover, the findings obtained from this research would contribute to the acknowledgement of protective factors, especially in crisis response studies in the fields of psychological counseling and guidance services. Based on these justifications, the general purpose of this research is to analyze perceived social support, depression and life satisfaction as the predictors of resilience in secondary school students of a low socioeconomic level (SEL). The analysis of the resilience levels of students was based upon gender, with whom the student lives, and whether their parents are together/separated and alive/not alive.

\section{Method}

\section{Research Design}

In the research, the relational screening method was used in order to analyze whether the "Resilience" of secondary school students of a low SEL differs based on gender, with whom the student lives, whether the parents are together/separated and alive/not alive, and whether perceived social support, life satisfaction and depression are significant predictors of resilience.

\section{Research Sample}

The research population consists of a total of 24 primary schools affiliated with the central district of Burdur with students in the sixth, seventh and eighth grades attending Turk Hava Kurumu, Sakarya, Cumhuriyet, Turan, Mehmetcik, İstiklal, Yardimseverler, Kemal Solmaz, and Vali Dr. Suleyman Oguz primary schools. Among these pupils are students from a low SEL. The concept of resilience, in the most general sense, can be defined as the ability to cope with difficult conditions of life. Low socioeconomic status negatively affects basic physiological needs, such as accommodation, nutrition and health, and the meeting of some psychological needs based on the educational level of the family. Being resilient is an important characteristic in order to cope with stress and the difficult conditions of life faced by those students living under such circumstances. For this reason, the research population consists of secondary school students of low socioeconomic status.

The sample group was selected based on the simple random sampling method where each student in the research population has an equal and independent chance of taking part in the sample group (Karasar, 2007). The sample group of the study 
consists of 386 students selected by the above method. Of the students in the sample, $202(52 \%)$ are girls, and $184(48 \%)$ are boys. Of these students, $130(34 \%)$ attend sixthgrade, 138 (36\%) attend seventh-grade, and 118 (30\%) attend eighth-grade schools.

\section{Research Instrument and Procedure}

Resilience Scale for Secondary School Students. In order to determine the resilience of the students, the Resilience Scale for Secondary School Students of 4 factors and 23 items developed by Sahin-Baltaci and Karatas (2014) was used. The first factor of the scale explains $14 \%$, the second factor explains $14 \%$, the third factor explains $11 \%$, and the fourth factor explains $9 \%$ of the total variance; all four factors explain $48 \%$ of the total variance. Cronbach's alpha coefficients of the scale are .85 for the entire scale, .75 for the sub-dimension of autogenous resilience, .78 for the subdimension of resilience stemming from the family, .72 for the sub-dimension of resilience stemming from a friend, and .73 for the sub-dimension of resilience stemming from the schoolteacher. The test-retest reliability coefficient of the scale is .85 .

The Brief Multidimensional Students' Life Satisfaction Scale (BMSLSS).In the assessment of life satisfaction, The Brief Multidimensional Students' Life Satisfaction Scale adapted by Siyez and Kaya (2008) was used. The test-retest reliability of BMSLSS was calculated as .82 and the internal consistency coefficient was calculated as .89 . The total correlation of the items in the scale varies between .64 and .78 . The internal consistency coefficient calculated within the scope of the research has been found to be .83 .

Social Support Appraisal Scale for Children and Adolescents. In order to measure perceived social support, the Social Support Appraisal Scale for Children and Adolescents, developed by Dubow and Ullman (1989) and adapted to Turkish by Gokler (2007), was used. The criterion validity of the scale was calculated as $r=-.62$ $(p<0.01)$ and the internal consistency coefficients obtained for sub-dimensions were calculated as $.89, .86$, and .88 respectively; the test-retest reliability coefficient was determined to be $.49(\mathrm{p}<0.01)$ for the entire scale; the split-half reliability was determined as .82; the item-total reliability relation of items with a total points was found to vary between .34 and .64. Cronbach's alpha internal consistency coefficient of the scale is .93. Cronbach's alpha internal consistency coefficient was calculated as .94 for this research.

Depression Scale for Children .In order to measure depression, the Depression Scale for Children, developed by Kovacs (1981) and adapted to Turkish by Oy (1990), was used. The test-retest reliability of the scale was found to be .80 . The criterion relative validity coefficient of the scale and the correlation of it with the childhood depression grading scale points is .61. The internal consistency coefficient calculated in this study is .80 .

Measures were administered to students in groups by researchers. The surveys were administered to students from one class from each grade selected at random. Students were informed about anonymity, privacy, and confidentiality and students were told that their responses would remain confidential and were asked to complete 
all of the questions in the measures. The instruments took approximately 35-40 minutes to complete. İnformed consent was received for all students who volunteered to participate in the study.

\section{Data Analysis}

Whether the data in this research met parametric statistical assumptions (such as the data indicating normal distribution, variances being homogenous and obtained with a uniform scale) was determined based on the properties of dependent and independent variables and the purposes of the research. A t-test was used to test the significance of the difference between the means of two independent groups, oneway analysis of variance was used to test the significance of the difference between the means of more than one independent group, and multi-standard linear regression analysis was used to explain the relationship between dependent variables and independent variables with a regression equation (Buyukozturk, 2010). According to this, a t-test was used to test whether students' resilience levels vary based on gender and with whom they live. One-way analysis of variance was used to test whether it varies based on the conditions of parents being together or separated and alive or not alive. Multi-standard linear regression analysis was used to test whether perceived social support, depression and life satisfaction are significant predictors of resilience.

\section{Results}

In the present study, whether resilience levels of secondary school students of a low SEL vary based on gender and with whom they live was tested with a t-test. The results are given in Table 1.

Table 1.

T-Test Results Based on Gender and the Person/People with Whom They Live

\begin{tabular}{llcccccc}
\hline & & $\mathrm{n}$ & $M$ & $\mathrm{~S}$ & $\mathrm{df}$ & $\mathrm{t}$ & $\mathrm{p}$ \\
\hline Gender & Female & 202 & 80,15 & 6,88 & & & \\
& Male & 184 & 78,74 & 8,60 & & & \\
& Mother and father & 341 & 79,97 & 7,46 & & & \\
$\begin{array}{l}\text { People } \\
\text { lived with }\end{array}$ & Single parent-relative & 45 & 75,75 & 9,040 & & & \\
\hline
\end{tabular}

${ }^{*} \mathrm{p}<.01$

As seen in Table 1, the results of the t-test indicated that females $(M=80,15)$ and males $(M=78,74)$ did not differ significantly or meaningfully on resilience, $t_{(384)}=1.78$, $\mathrm{p}>$.05. According to this, the resilience of females and males do not vary. Again, according to Table 1, the difference between the means of the resilience of students 
living with their mother and father $(M=79,97)$ and those living with one of their parents or a relative $(M=75,75)$ was found to be statistically significant $\left(t_{(384)}=4.47\right.$, $\mathrm{p}<.01$ ). According to this finding, the resilience of students living with their parents is higher than those living with one of their parents or a relative.

Another variable analyzed in this research project was whether resilience levels differ based on the status of the mother-father being together/separated and alive/not alive. This variable was analyzed with one-way analysis of variance. A Tukey post hoc test was conducted to find the source of the difference, and the results are given in Table 2 .

Table 2.

ANOVA Results Based on the Status of Mother and Father

\begin{tabular}{|c|c|c|c|c|c|c|c|c|}
\hline $\begin{array}{c}\text { Source of } \\
\text { variance }\end{array}$ & & $\mathrm{n}$ & $M$ & $\mathrm{~S}$ & $\mathrm{~F}$ & $\mathrm{p}$ & $\eta^{2}$ & (Tukey) \\
\hline \multirow{3}{*}{$\begin{array}{l}\text { Status of mother } \\
\text {-father alive-not } \\
\text { alive/together- } \\
\text { separated }\end{array}$} & $\begin{array}{l}\text { Mother- } \\
\text { father } \\
\text { together(A) }\end{array}$ & 345 & 79,99 & 7,47 & & & & \multirow{3}{*}{$\begin{array}{l}\text { A-B, } \\
\text { A-C }\end{array}$} \\
\hline & $\begin{array}{l}\text { Mother- } \\
\text { father } \\
\text { separated } \\
\text { (B) }\end{array}$ & 29 & 75,52 & 8,69 & $7,50^{*}$ & .001 & .038 & \\
\hline & $\begin{array}{l}\text { Mother / } \\
\text { father not } \\
\text { alive(C) }\end{array}$ & 12 & 74,25 & 9,76 & & & & \\
\hline
\end{tabular}

${ }^{*} \mathrm{p}<.01$

Table 2 shows the findings comparing students' resilience based on whether the mother and father are together/separated and alive/not alive. An examination of Table 2 shows a significant difference between the resilience of students whose parents are together and those who have separated and/or whose mother or father is not alive $(\mathrm{F}(2-383)=7,50, \mathrm{p}<.01)$. According to the results of the Tukey test, the resilience levels of students whose parents are together are higher compared to students whose parents have separated and whose mother/father is/are not alive. The effect size for these differences was small, $\eta^{2}=.038$.

\section{Findings regarding the Predictors of Resilience}

In regression analysis, dependent and independent variables should be continuous variables that are measured with an interval scale and the data should indicate normal distribution. Before analysis, the data was checked to establish 
whether it had a normal distribution. İt was determined that skewness and kurtosis values in all variables were between -1.0 and +1.0 (Buyukozturk, 2007). It was observed that the data had a normal distribution. In addition, the data were controlled whether they were coherent to univariate and multivariate analyses. The Mahalonobis distance coefficient and $\mathrm{z}$ point analysis was conducted for outlier analysis in the data set. A $z$ table value at the level of 0.01 for the extreme values with a single variable was checked, either in ascending or in descending order; no data exceeded 3.29 (Tabachnick \& Fidell, 2007). Mahalanobis distance was analyzed for the extreme values with a multivariable and no values over 1 were found. Finally, prior to regression analysis, correlation coefficients between dependent and independent variables were calculated in order to analyze whether there is multicollinearity between the dependent and independent variables. The results are given in Table 3.

\section{Table 3.}

Simple Linear Correlation Coefficients Indicating the Relationships between Resilience Levels and Levels of Perceived Social Support, Life Satisfaction and Depression of Students

\begin{tabular}{|c|c|c|c|c|c|c|}
\hline \multirow{2}{*}{$\begin{array}{l}\text { Variables } \\
\text { Resilience }\end{array}$} & \multirow{2}{*}{$\frac{M}{79,48}$} & \multirow{2}{*}{$\frac{S}{15,26}$} & \multicolumn{4}{|c|}{ Pearson Correlation Coefficients $(n=386)$} \\
\hline & & & 1 & 2 & 3 & 4 \\
\hline $\begin{array}{l}\text { Social } \\
\text { Support }\end{array}$ & 166,95 & 23,96 & $.492^{* *}$ & - & & \\
\hline $\begin{array}{l}\text { Life } \\
\text { Satisfaction }\end{array}$ & 35,22 & 5,66 & $.478^{* *}$ & $.496^{* *}$ & & \\
\hline Depression & 9,94 & 5,88 & $-.373^{* *}$ & $-.557^{* *}$ & $-.545^{\star *}$ & - \\
\hline
\end{tabular}

According to Table 3, there is a positive significant relationship of resilience to social support and life satisfaction of the students and a significant negative mediumlevel relationship to depression. However, significant medium-level relationships were found between independent variables. It can be said that this relationship is not of a level to cause multicollinearity according to Buyukozturk (2010). In consideration of the Durbin Watson value used in the model to test autocorrelation, the value, which is desired to be between 1.5 and 2.5 (Kalayci, 2006), was also found to be 1.783 . This value indicates that there is no autocorrelation in the model. The results obtained from the Multiple Standard Regression Analysis, which was conducted after proving the conformity of the data to multiple regression analysis but prior to regression analysis, are given in Table 4 . 
Table 4.

Results of Multiple Regression Analysis

\begin{tabular}{llllllll}
\hline & $\mathrm{B}$ & $\mathrm{S}$ & $\beta$ & $\mathrm{t}$ & $\mathrm{p}$ & $\mathrm{R}$ & $\mathrm{R}^{2}$ \\
\hline Constant & 47,523 & 3,780 & & 12,574 & & & \\
Social &, 106 &, 017 &, 328 & $6,180^{*}$ & .000 & & \\
$\begin{array}{l}\text { Support } \\
\text { Life }\end{array}$ &, 413 &, 072 &, 301 & $5,738^{*}$ & .000 & .56 & .31 \\
$\begin{array}{l}\text { Satisfaction } \\
\text { Depression }\end{array}$ &,- 035 &, 073 &,- 026 &,- 478 & .633 & & \\
& \multicolumn{2}{l}{$\mathrm{F}(3-382)=58,608, \mathrm{p}<.001$} & & & & \\
\end{tabular}

In Table 4, perceived social support and life satisfaction are observed to be significant predictors of resilience, whereas depression is not a significant predictor of resilience despite its indicating a significant negative correlation with resilience. Perceived social support and life satisfaction explain $31 \%$ of the total variance $(R=.56$, $\left.\mathrm{R}^{2}=.31, \mathrm{~F} \quad(3-382)=58.61, \mathrm{p}<.001\right)$. In consideration of the signs of regression coefficients of predictor valuables, it is observed that there is a positive significant relationship between social support, life satisfaction and resilience. Analysis of standardized regression coefficients $(\beta)$ indicates that the order of importance for predictor valuables on resilience level is social support and life satisfaction.

\section{Discussion and Suggestions}

According to the results obtained in the study, the resilience levels of secondary school students of a low SEL do not vary based on gender. This finding is supported by the research findings of Ozcan (2005), Terzi (2008), and Kirimoglu, Yildirim and Temiz (2010). Contrary to those studies, other research states that resilience does vary based on gender (Dayioglu, 2008; Onder \&Gulay, 2008; Sipahioglu, 2008; Oktan, 2008; Onat, 2010; Savi Cakar \& Karatas, 2011; Yilmaz \& Sipahioglu, 2011). The differences between findings might stem from the data collection tools used in the studies and the general characteristics of the study groups in which each study was conducted.

According to another finding, resilience levels of students living with their parents are higher than those living with one of their parents or their relatives. The most important transference of familial support is provided through emotional channels and feeds communication in a positive way. Within the period when adolescence appears, they need reliable ties with their acquaintances and a healthy environment where emotional communication channels are open (Ergun, 2008). Family is among the important social support systems in the lives of individuals. For 
this reason, it is expected that the resilience levels of students living with their parents are higher compared to others.

In the study, the resilience levels of students whose parents are together were found to be higher than that of students whose parents were separated and those whose parents were not alive. Soest, Mossige, Stefansen and Hjemdal (2009) also stated that positive family characteristics affect the resilience of children positively. Moreover, Ozcan (2005) found that students whose parents are together have a higher level of resilience compared to those whose parents are divorced. This result can be explained as the mother and father being perceived as a social support and power within society. Students are able to use this power when coping with difficult situations, in addition to the importance attributed to the nuclear family structure within society. İn communitarian cultures, such as Turkish society, family members do not ignore problems of other members, as social support and mutual affinity are important in communitarian cultures. Also, in these groups there is a strong commitment to groups and a lifelong unquestioned loyalty to this commitment (Kagitcibasi, 2006).

Another result obtained from the research suggests that perceived social support and life satisfaction significantly predict resilience in secondary school students of low SEL,yet depression does not significantly predict that. Similarly, Dayioglu (2008) found that social support is a significant predictor of resilience in high school students, and Savi Cakar and Karatas (2011) found the same in adolescents. In the measuring tool he/she developed, Bayrakli (2010) stated that social support predicts resilience significantly and it is an important variable with regard to resilience. In their study, Losel, Bliesener and Koferl (1989) pointed out the support of adults, who are important in the child's life, as the protective factor in resilience (cited in Goldstein \&Brooks, 2006). While affection and support from basic systems such as family, school, and society are among the important variables that affect resilience in preadolescents' lives, (Rhodes \&Brown, 1991), family and other social support networks in particular are stated to be protective factors (Friborg, Hjemdal \& Rosenvinge, 2006; Luthar, Cicchetti \& Becker, 2000). In addition, individuals with strong social support systems are noted to be able to cope with stressful life events easier and suffer from lower levels of anxiety, depression, and behavioral problems compared to those with weaker systems of social support (Barrera, Fleming \&Khan, 2004; Callaghan \& Morrisey, 1993; Lara, Leader \&Klein, 1998).

Finding pleasure in life and the increase of satisfaction in an individual's life are correlated with developing positive feelings and emotions for themselves. Resilience would inevitably be influenced at the same rate as the increase in life satisfaction of individuals. İn the study on individuals affected by an earthquake, Karairmak (2007) found that resilience is correlated with life satisfaction. Oktan (2008) arrived at the conclusion that the life satisfaction of adolescents preparing for the university examination significantly predicts their resilience. Moreover, it has been detected that adolescents with a high level of life satisfaction also have a high level of resilience, while ones with a low level of life satisfaction also have a low level of resilience. These findings support the results of this study. In consideration of another finding of the study, despite the fact that depression alone provides a 
significant negative correlation with resilience, the lack of a significant predictor in the model. Social support and life satisfaction could have reduced the effects of depression

In accordance with the results of the research, several suggestions can be made for psychological counselors of schools and researchers. First of all, in order to increase their resilience abilities, psychological-training can be provided through counseling in schools for students who live with only one of their parents or with their relatives. Within the scope of student personality services, various social support resources can be allocated for secondary school students whose parents have separated and the father/mother is/are not alive. Since social support and life satisfaction are important variables in regard to resilience, an appropriate educationteaching environment can be provided for such studies to be conducted at schools. In consideration of schools as important social support elements, increasing school services that meet the needs of the students, and transforming the school into an important living area for the students to love, can be useful. This can be achieved through sports activities, functional clubs, and the establishment of environments where students can comfortably express themselves. In order to increase resilience levels, psycho-training programs targeting risk groups can be developed and these programs can be experimentally tested. The most important restriction of this study is that the sample group consisted of students living in Burdur, a small city that does not receive many immigrants. For this reason the findings cannot be generalized to all students of this age. Further studies on the resilience levels of students in this age group, and in wider groups, should be undertaken.

\section{References}

Ahern, N.R., Ark, P., \& Byers, J. (2008). Resilience and coping strategies in adolescents. Pediatric Nursing, 20 (10), 32-36.

Barrera, M., Fleming, C. F.,\& Khan, F. S. (2004). The role of emotional social support in the psychological adjustment of siblings of children with cancer. ChildCare Health and Development, 30(2), 103-111.

Bayrakli, H. (2010). Zihinsel engelli ve engelli olmayan cocuga sahip annelerde yilmazliga etki eden degiskenlerin incelenmesi [Investigating the factors affecting resiliency in mothers of mentally retarded and nondisabled children]. (Yayinlanmamis yuksek lisans tezi). Ankara Universitesi, Egitim Bilimleri Enstitusu, Ankara.

Benard, B. (1991). Fostering resiliency in kids: Protective factors in the family, school and community. National Resilience Resource Center, University of Minnesota, ISBN: 0-309-12675-4,USA. 
Buyukozturk, S. (2010). Sosyal bilimler icin veri analizi el kitabi [Manuel data analysis for the social sciences]. Pegem Akademi, Ankara.

Callaghan, P., \& Morrissey, J. (1993). Social support and health: A review. Journal Adv Nurs, 18, 203-210.

Cicchetti, D., \& Toth, S. (1998). The development of depression in children and adolescents. American Psychologist, 53, 221-24.

Clinton,J. (2008). Resilience and recovery. International Journal of Children's Spirituality, 13(3), 213-222.

Cobb, S. (1976). Social support as a moderator of life stress. Psychosom Med, 38, 300314.

Coleman, N. (2015). Promoting resilience through adversity: Increasing positive outcomes for expelled students. Educational Studies, 41(1-2), 171-187.

Celikel-Cam, F., \& Erkorkmaz, U. (2008). Universite ogrencilerinde depresif belirtiler ve umutsuzluk duzeyleri ile iliskili etmenler [Factors related to depressive symptoms and hopelessness among university students]. Noropsikiyatri Arsivi, $45,122-129$.

Davis, M.C., Luecken, L., \& Lemery-Chalfant, K. (2009). Resilience in common life: Introduction to the special issue. Journal of Personality 77(6), 1637-1644.

Dayioglu, B. (2008). Universite giris sinavina hazirlanan adaylarda psikolojik saglamlik: ogrenilmis gucluluk, algilanan sosyal destek ve cinsiyetin rolu [Resilience in university entrance examination applicants: The role of learned resourcefulness, perceived social support, and gender]. (Yayinlanmamis yuksek lisans tezi).Ortadogu Universitesi, Sosyal Bilimler Enstitusu, Ankara.

Eminagaoglu, N. (2006). Guc kosullarda yasayan sokak cocuklarinda dayaniklilik (saglamlik) [Resilience (hardiness) of street children living in difficult conditions]. (Yayinlanmamis doktora tezi). Ege Universitesi, Sosyal Bilimler Enstitusu, İzmir.

Erdogan, G. (2006). Ilkogretim 8. Sinif (14-15 yas) Ogrencilerinin depresif belirti ve ozkavram duzeylerine yaratici drama calismalarinin etkililiginin incelenmesi [The effects of creative drama on the self-concept and depressive symptoms of 8th grade (ages 14-15) students with depressive symptoms]. (Yayinlanmamis yuksek lisans tezi). Gazi Universitesi, Egitim Bilimleri Enstitusu Ankara.

Gokler, İ. (2007). The standardization study of social support assessment scale for child and adolescent: factoral structure, validity and reliability. Journal of Child and Adolescent Mental Health, 12(2), 83-91. 
Fergus, S., \& Zimmerman, M.A. (2005). Adolescent resilience: A framework for understanding healthy development in the face of risk. Annu. Rev. Public Health, 26, 399-419.

Gizir, C. A. (2004). Akademik saglamlik: Yoksulluk icindeki sekizinci sinif ogrencilerinin akademik basarilarina katkida bulunan koruyucu faktorlerin incelenmesi [Academic resilience: an investigation of protective factors contributing to the academic achievement of eight grade students in poverty]. (Yayinlanmamis doktora tezi). Orta Dogu Teknik Universitesi, Sosyal Bilimler Enstitusu, Ankara.

Goldsteine, S., \& Brooks, R.B. (2006).Handbook of resilience in children. United States of America: Springer.

Gokden-Kaya, N. (2007). Yatili ilkogretim bolge okulu ikinci kademe ogrencilerinde saglamligin icsel faktorlerini yordamada benlik saygisi, umut ve dissal faktorlerin rolu[The role of self-esteem, hope and external factors in predicting resilience among regional boarding elementary school students]. (Yayinlanmamis yuksek lisans tezi).Ortadogu Teknik Universitesi, Sosyal Bilimler Enstitusu, Ankara.

Greene, R. (2002). Human behavior theory: A resilience orientation. In R. Greene (Ed.), Resiliency: An integrated approach to practice, policy, and research.Washington, DC: NASW Press.

Guloglu, B.,\& Karairmak, O. (2010). Universite ogrencilerinde yalnizligin yordayicisi olarak benlik saygisi ve psikolojik saglamlik [Self-esteem and resilience as the predictors of loneliness among university students].Ege Egitim Dergisi, 11(2),73-88.

Hand, M.P. (2008). Psychological resilience. Saarbrucken, Germany: VDM Verlag Dr. Muller Aktien Gesellschaft \& Co. KG.

Hanewald, R. (2011). Reviewing the literature on "at-risk" and resilient children and young people.Australian Journal of Teacher Education, 36(2), 16-29.

Joshanloo, M. (2013). The influence of fear of happiness beliefs on responses to the satisfaction with life scale. Personality and Individual Differences, 54, 647-651.

Kagitcibasi,C. (2006). İnsan ve insanlar [New people and people]. Evrim yayincilik, İstanbul.

Kaner, S., Bayrakli, H.,\& Guzeller, C.O. (2011). Anne-babalarin yilmazlik algilarinin bazi degiskenler acisindan incelenmesi [Investigating perception of parental resilience in terms of some variables]. Ankara Universitesi Egitim Bilimleri Fakultesi Ozel Egitim Dergisi, 12(2) 63-78. 
Karairmak, O. V., \& Sivis-Cetinkaya, R. (2011). Benlik saygisinin ve denetim odaginin psikolojik saglamlik uzerine etkisi: duygularin araci rolu. [The effect of selfesteem and locus of control on resilience: The mediating role of affects].Turk Psikolojik Danisma ve Rehberlik Dergisi, 4 (35), 30-43.

Karairmak, O. (2006). Resilience, risk and protective factors.Turkish Psychological Counseling and Guidance Journal, 3(26), 129-142.

Karasar, N. (2007). Bilimsel arastirma yontemleri[Research methods].Nobel Yayin Dagitim. Ankara.

Karatas, Z., \& Savi Cakar, F. (2011). Self-esteem and hopelessness, and resiliency: An exploratory study of adolescents in Turkey. International Education Studies, 4(4), 84-91.

Kirimoglu, H., Yildirim, Y., \& Temiz, A. (2010). İlk ve ortaogretim okullarinda gorev yapan beden egitimi ve spor ogretmenlerinin yilmazlik duzeylerinin incelenmesi (Hatay ili ornegi) [A research on resiliency of physical education and sports teachers that work in primary and secondary education schools (Example of hatay province)].Nigde Universitesi Beden Egitimi ve Spor Bilimleri Dergisi,4(1),88-97.

Lara, M. E., Leader, J., \& Klein, D. N. (1998). What is social support? Harvard Mental Health Letter, 14(12), 6-8.

Luthar, S., Cicchetti, D., \& Becker, B. (2000). The construct of resilience: A critical evaluation and guidelines for future work. Child Development, 71(3), 543-562.

Malkoc, A. \& Yalcin, I. (2015). Universite Ogrencilerinde Psikolojik Dayaniklilik, Sosyal Destek,Basa Cikma ve İyi-Olus Arasindaki İliskiler[Relationships among resilience, social support, coping, and psychological well-being among university students]. Turk Psikolojik Danisma ve Rehberlik Dergisi, 5(43), 35-43.

Masten, A. S. (1994). Resilience in individual development: Successful adaptation despite risk and adversity. In M.C. Wang E.W. Gordon (Eds.), Educational resilience in inner-city America: Challenges and Prospects (3-25). Hillsdale, NJ: Lawrance Erlbaum.

Masten, A. S. (2001). Ordinary magic: resilience processes in development. American Psychologist, 56(3), 227-238.

McDowell, İ. (2010). Measures of self-perceived well-being. Journal of Psychosomatic, 69, 69-76.

Oktan, V. (2008). Universite sinavina hazirlanan ergenlerin psikolojik saglamliklarinin cesitli degiskenlere gore incelenmesi [Investigate resilience of adolescents who are getting prepared for the university entrance exam]. (Yayinlanmamisdoktora tezi). Karadeniz Teknik Universitesi, Sosyal Bilimler Enstitusu, Trabzon. 
Ogulmus, S. (2001, Mart).Bir kisilik ozelligi olarak yilmazlik [Resilience as a personality trait] İ. Ulusal Cocuk ve Suc Sempozyumu: Nedenler ve Onleme Calismalari, Sozlu bildiri olarak sunulmustur, Ankara.

Onder,A.,\&Gulay, H. (2008). Ilkogretim 8. sinif ogrencilerinin psikolojik saglamliginin cesitli degiskenler acisindan incelenmesi [Resilience of 8. Grade students in relation to various variables]. Dokuz Eylul Universitesi Buca Egitim Fakultesi Dergisi, 23, 192-197.

Oy, B. (1991). Cocuklar icin depresyon olcegi gecerlik ve guvenirlik calismasi [Validity and reliability studies of depression scale for children]. Turk Psikiyatri Dergisi, 2, 132-136.

Oz, F., \& Bahadir-Yilmaz, E. (2009). Ruh sagliginin korunmasinda onemli bir kavram: psikolojik saglamlik [A significant concept in protecting mental health: Resilience]Hacettepe Universitesi Saglik Bilimleri Fakultesi Hemsirelik Dergisi, 8289.

Reich, J.W., Zautra, A.J., \& Hall, J.S. (2010).Handbook of adult resilience. New York, London: The Guilford Press.

Rose, J., \& Steen, S. (2015). The achieving success everyday group counseling model: Fostering resiliency in middle school students. Professional School Counseling, 18(1), 28-37.

Salami, S.O. (2010). Moderating effects of resilience, self-esteem and social support on adolescents' reactions to violence. Asian Social Science, 6(12), 101-110.

Savi-Cakar, F.,\& Karatas, Z. (2011). Ergenlerin yilmazlik duzeyleri ile algiladiklari sosyal destek arasindaki iliski [The relationship between the resilience level of adolescents and perceived social support]. Cagdas Egitim Dergisi, 36(387), 12 20.

Savi-Cakar, F. Karatas, Z., \&, Cakir, M.A. (2014).Yetiskin yilmazlik olcegi: Turk

kulturune uyarlanmasi[An adaptation the resilience in midlife scale to Turkish adults]. Mehmet Akif Ersoy Universitesi Egitim Fakultesi Dergisi, 32, 22-39.

Shonkoff, J. P. (1984). Social support and the development of vulnerable children. Am. Journal Public Health, 74 (4), 310-312.

Sipahioglu, O. (2008). Farkli risk gruplarindaki ergenlerin psikolojik saglamliklarinin incelenmesi [Investigating resilience of adoloscents'in different risk groups]. (Yayinlanmamisyuksek lisans tezi). Selcuk Universitesi, Sosyal Bilimler Enstitusu, Konya. 
Siyez, D. M.,\& Kaya, A. (2008). Validity and Reliability of the Brief Multidimensional Students' Life Satisfaction Scale with Turkish Children. Journal of Psychoeducational Assessment, 26 (2), 139-147.

Smith, P.R. (2009). Resilience: Resistance factor for depressive symptom. Journal of Psychiatric and Mental Health Nursing, 16, 829-837.

Soest, T., Mossige, S., Stefansen, K., \& Hjemdal, O. (2009). A validation study of the resilience scale for adolescents (READ). Journal of Psychopathology and Behavioral Assessment, 32 (2), 215-225.

Steinberg, L. (2002). Adolescence. (Sixth Edition). Boston: Mc Graw Hill, 444-452.

Sahin-Baltaci, H. (2013). Turkish 6 th -8th grade students' social emotional learning skills and life satisfaction. International Journal on New Trends in Education and Their Implications, 4 (2), 1-14.

Sahin-Baltaci, H.,\& Karatas, Z. (2014). Validity and reliability of the resilience scale for early adolescents.Procedia - Social and Behavioral Sciences, 131, 458-464.

Tabachnick, B. G., \& Fidell, L.S. (2007). Using Multivariate Statistics, (5th Ed.). Needham Heights, MA: Allyn and Bacon Publishers.

Terzi, S. (2008). Universite ogrencilerinde kendini toparlama gucunun icsel koruyucu faktorlerle iliskisi [The relationships between resilience and internal protective factors in university students]. Hacettepe Universitesi Egitim Fakultesi Dergisi, 35, 297-306.

Werner, E. E.,\& Smith, R. S. (1982). Vulnerable but invincible: A longitudinal study of resilient children and youth. New York: McGraw-Hill.

Wilks, S.E., \& Spivey, C.A. (2010). Resilience in undergraduate social work students: Social support and adjustment to academic stress. Social Work Education, 29(3), 276-288.

Yilmaz, H., \& Sipahioglu, O. (2012). Farkli risk gruplarindaki ergenlerin psikolojik saglamliklarinin incelenmesi [İnvestigating resilience of adolescents in different risk groups]. İlkogretim Online, 11(4), 927-944. 


\title{
Ortaokul Öğrencilerinin Yılmazlık Düzeylerinin Yordayıcısı olarak Algılanan Sosyal Destek, Depresyon ve Yasam Doyumu: Burdur Örneği
}

\author{
Atıf: \\ Sahin-Baltaci, H., \& Karatas, Z. (2015). Perceived social support, depression and life \\ satisfaction as the predictor of the resilience of secondary school students: The \\ case of Burdur. Eurasian Journal of Educational Research, 60, 111-130 \\ 10.14689/ejer.2015.60.7
}

\begin{abstract}
Özet
Problem Durumu: Y1lmazlık, stresle ya da zor durumlarla bas etme ve uyum sağlama yeteneği olarak tanımlanır. Sıkıntılı durumlara başarılı bir uyum olarak tanımlanan bu süreçte bireyin kişilik özellikleri önemli bir etkendir. Yılmazlık ile ilgili kuramsal yapı incelendiğinde içsel ve dışsal koruyucu faktörlerin yılmazlığın gelişmesinde etkili olduğunu savunan modeller olduğu görülmektedir. Yetişkin desteği çocuğun sorunları görebilmesinde ve çözebilmesinde önemli koruyucu faktörlerden birisidir. Sosyal destek sağlıklı olma davranışlarının sürekliliğinde önemli değişkenlerden birisi olarak ifade edilmektedir. Erken çocukluk yıllarında dünyaya negatif bakış açısı ile bakma bireylere, kendilerini hayal kırıklı̆̆ına uğramayı öğretmektedir. İlgili alanyazın incelendiğinde, yılmazlık ile ilgili çalışmaların daha çok lise ve üniversite öğrencilerine yönelik olduğu görülmektedir. Yılmazlık, genellikle zor yasam koşulları ile baş etme söz konusunda olduğunda önemli bir özellik olarak karşımıza çıkmaktadır. Yaşça daha küçük çocukların zorlu yasam koşulları ile baş etmeleri yaşça büyüklere oranla daha zor olabilir. Çünkü yas büyüdükçe, zor yasam koşulları ile baş etmede ise yarayacak bilgi ve becerilere sahip olma şansı artabilir. Bu nedenle on ergenlik sorunlarının yanı sıra, düşük sosyo ekonomik düzeyin getirdiği olumsuzluklarla baş etmede önemli olan yılmazlığın yordayıcılarını saptamak, bu yas grubuna yönelik yapılacak psiko-egitim programlarının içeriği açısından fikir verebilir.
\end{abstract}

Araştırmanın Amacı: Bu araştırmanın amacı; sosyo ekonomik düzeyi düşük ortaokul öğrencilerinin yılmazlık düzeylerini çeşitli demografik değişkenlere göre ve algılanan sosyal destek, depresyon ve yasam doyumunun öğrencilerin yılmazlık düzeylerinin anlamlı yordayıcısı olup olmadığını incelemektir.

Araştırmanın Yöntemi: Araştırmada ilişkisel tarama yöntemi kullanılmıştır. Araştırma evreni, Burdur merkez ilçeye bağlı düşük SED'deki öğrencilerin devam ettiği sekiz ilköğretim okulunun 6,7 ve 8 . Sınıf öğrencilerinden oluşmaktadır. Örneklem, basit seçkisiz örnekleme yöntemi kullanılarak seçilen 386 öğrenciden oluşmaktadır. Veriler, Ortaokul Öğrencileri için Yılmazlık Ölçeği, Çok Boyutlu Öğrenci Yasam Doyum Ölçeği-Kısa Formu, Çocuk ve Ergenler İçin Sosyal Destek Değerlendirme Ölçeği, Çocuklar için Depresyon Ölçeği ve kişisel bilgi formu ile elde edilmiştir. Öğrencilerin yılmazlık düzeylerinin cinsiyet ve kiminle yaşadığına göre farklılaşıp 
farklılaşmadığını test etmek için $\mathrm{t}$ testi, aile yapısına (birlikte, ayrı, hayatta değil) göre farklılaşıp farklılaşmadığını test etmek için tek yönlü Varyans Analizi, algılanan sosyal destek, depresyon ve yasam doyumunun öğrencilerin yılmazlık düzeylerinin anlamlı yordayicilari olup olmadığını belirlemek için ise çoklu standart doğrusal regresyon analizi kullanılmıştır.

Araştırmanın Bulguları: Araştırmada, kız ve erkeklerin yılmazlık puan ortalamaları arasındaki fark istatistiksel olarak anlamlı bulunmazken $(\mathrm{t}(384)=1.78, \mathrm{p}>.05)$, anne babası ile yasayan öğrencilerin ve ebeveynlerinden biri ya da akrabaları ile yasayan öğrencilerin yılmazlık puan ortalamaları arasındaki fark istatistiksel olarak anlamlı bulunmuştur $(\mathrm{t}(384)=4.47, \mathrm{p}<.01)$. Bir diğer bulguya göre, anne-babası birlikte olan ögrencilerin yılmazlık puan ortalamaları ile anne-babası ayrı olanların ve anne ya da babası hayatta olmayan öğrencilerin yılmazlık puan ortalamaları arasında anlamlı bir fark vardır $(\mathrm{F}(2-383)=7,50, \mathrm{p}<.01)$. Son olarak, algilanan sosyal destek ve yasam doyumu toplam veryansın \% 31'ini açıklamaktadır $(\mathrm{R}=.56, \mathrm{R} 2=.31 \mathrm{~F}(3-382)=58.61$, $\mathrm{p}<.001)$. Yordayıcı değişkenlerin regresyon katsayılarının işaretlerine bakıldığında; sosyal destek yasam doyumu ile yılmazlık arasında pozitif anlamlı bir ilişki olduğu görülmektedir. Standardize edilmiş regresyon katsayıları incelendiğinde $(\beta)$, yordayıcı değişkenlerin yılmazlık düzeyi üzerindeki önem sırası sosyal destek ve yasam doyumu seklindedir.

Araştırmanın Sonuçları ve Öneriler: Öğrencilerin yılmazlık düzeyleri cinsiyete göre anlamlı bir farklılık göstermemektir. Anne babası ile yasayan öğrencilerin yılmazlık düzeyleri ebeveynlerinden biri ya da akrabaları ile yasayan öğrencilerin yılmazlık düzeyinden yüksektir. Anne babası birlikte olan öğrencilerin yılmazlık düzeyleri, anne babası ayrı olan ve anne ya da babası hayatta olmayan öğrencilerin yılmazlık düzeylerine göre daha yüksektir. Son olarak, algilanan sosyal destek ve yasam doyumunun yılmazlığı anlamlı olarak yordadığı, depresyonun ise yılmazlığın anlamlı yordayıcısı olmadığı saptanmıştır. Öncelikle, okul psikolojik danışmanları tarafından, ebeveynlerinden biri ya da akrabaları ile yasayan ortaokul öğrencilerine yılmazlık becerilerini artırmaya yönelik psiko-eğitimler verilebilir. Araştırmadan elde edilen sonuçlarına göre öneriler; öğrenci kişilik hizmetleri kapsamında, anne babası ayrı ve anne/babası hayatta olmayan ortaokul öğrencilerine yönelik çeşitli sosyal destek kaynakları oluşturulabilir. Sosyal destek ve yasam doyumu yılmazlık için önemli değişkenler olduğundan okullarda yapılacak çalışmalarda sosyal desteği ve yasam doyumunu arttırıcı uygun eğitim-öğretim ortamı sağlanabilir. Okulların önemli birer sosyal destek unsuru olduğu düşünülürse okul olanaklarının öğrencilerin yararına arttırılması, öğrencilerin okulu sevmeleri için okulu onlar için önemli bir yasam alanı haline getirilmesi faydalı olabilir. Bu durum çeşitli sportif faaliyetler, işlevsel kulüpler ve öğrencilerin kendilerini rahat ifade edebilecekleri ortamlar yaratılması ile sağlanabilir. Riskli gruplara yönelik yılmazlık düzeyini artırmak amaçlı psiko-egitim programları geliştirilip, bu programlar deneysel olarak sınanabilir. Bu araştırmanın en önemli sinirliliği örneklem gurubunun sadece küçük ve göç almayan bir il olan Burdur'da yasayan öğrencilerden oluşmasıdır. Bu nedenle bulgular bu yastaki tüm öğrencilere genelleyemez.

Anahtar Sözcükler: İyi oluş, cinsiyet, stresli yasam olayları, ergenler 
